\title{
UNIQUe VANADIUM-RICH EMERALD From Malipo, ChINA
}

Yang Hu and Ren Lu

Emeralds were discovered in Malipo County in southwestern China more than 30 years ago. Malipo emeralds are still being extracted and are expected to be available over the next decade. This study provides a full set of data through standard gemological properties, inclusion scenes, color characteristics, and advanced spectroscopic and chemical analyses including Raman, XRD, micro UV-Vis-NIR, EPR, and LA-ICP-MS. Multiphase inclusions in Malipo emerald are distinct with various shapes and occasionally a colorless transparent crystal. Abundant vanadium substitutes for aluminum in the octahedral site and serves as the predominant coloring agent, leading to a yellowish green color. Among significant known deposits, Malipo emerald has a unique chemical composition in its combination of high $\mathrm{V}$, low $\mathrm{Cr}$, and moderate $\mathrm{Fe}$, as well as high Li and $\mathrm{Cs}$ concentrations.

M alipo County in Yunnan Province of south western China is a valuable source of emerald (figure 1). The mine is located near the village of Dayakou in the Wenshan Autonomous Prefecture, about $30 \mathrm{~km}$ from the border city of $\mathrm{Ha}$ Giang, Vietnam (figure 2). Emerald was first mined as an accessory mineral from a tungsten deposit. Over the past two decades, large quantities of emerald have been extracted and collected as mineral crystal specimens or fashioned into carvings of traditional Chinese objects and themes. Some gemquality crystals have been cut into cabochons for jewelry use (figure 3). This is the only commercial emerald source being actively mined in China.

Previous studies of Malipo emeralds focused mainly on the regional geology, metallogenic conditions, and mineralogical properties (Zhang et al., 1998, 1999; Zhang and Lan, 1999; Xue et al., 2010; Huang et al., 2015, 2017). However, some significant gemological features of these emeralds were still insufficiently studied, including multiphase inclusion scenes, color characteristics, and chemical composition analysis. These features significantly affect identification and evaluation, as well as geographic origin determination.

This article provides an overview of the history, resource potential, and geology for Malipo emeralds.

See end of article for About the Authors and Acknowledgments.

Gems \& Gemology, Vol. 55, No. 3, pp. 338-352,

http://dx.doi.org/10.5741/GEMS.55.3.338

(C) 2019 Gemological Institute of America
Standard gemological techniques were used to characterize this material. Multiphase inclusion scenes

Figure 1. A traditional carved snuff bottle $(7.5 \times 11$ $\mathrm{cm}$ ) of emerald from Malipo with a lid made of garnet from the nearby town of Maguan. The carving also contains associated quartz at the bottom of bottle. Photo courtesy of Daowen Ye.

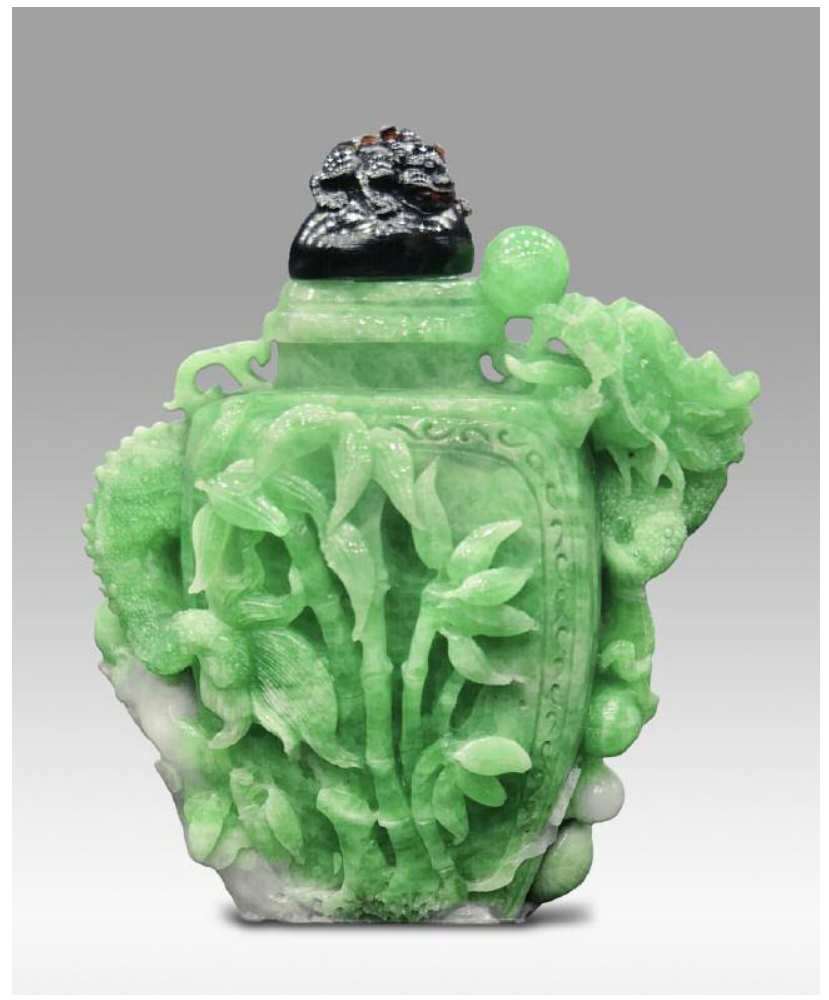



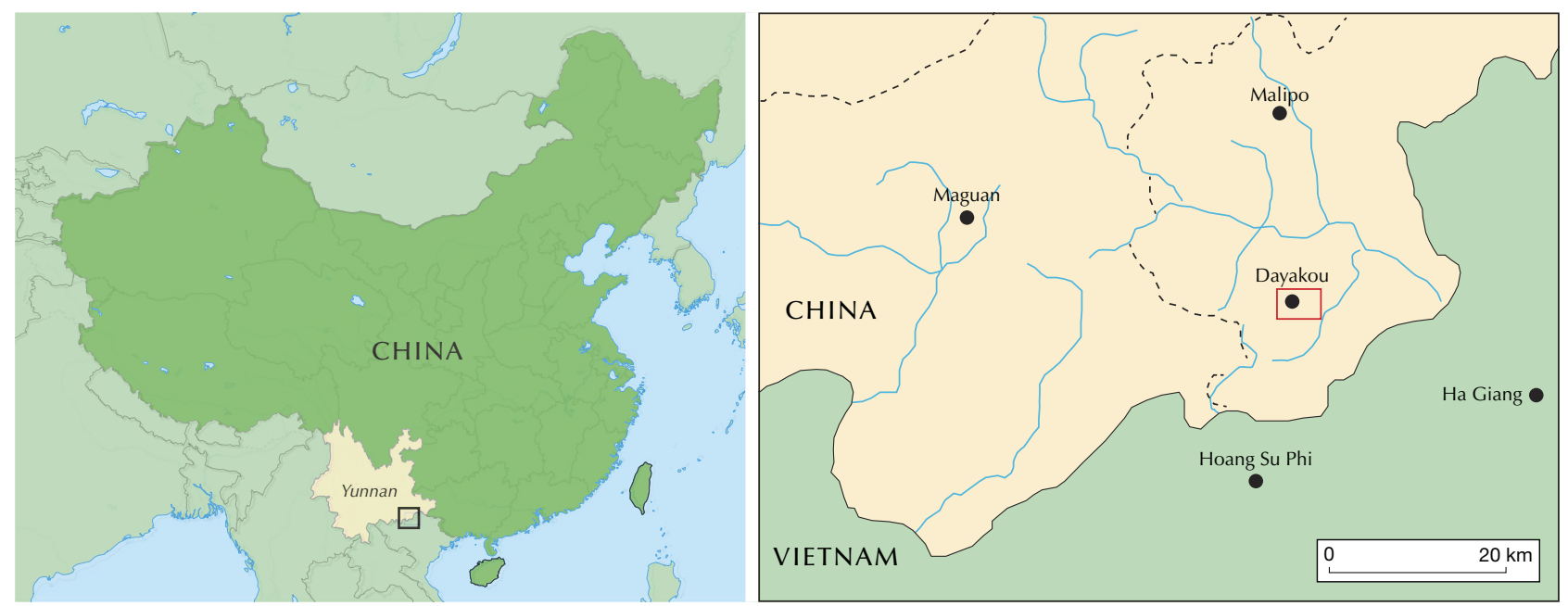

Figure 2. The emerald mine in Malipo County is located near the village of Dayakou in the southeastern region of Yunnan Province, about $20 \mathrm{~km}$ from the Vietnamese border. The red rectangle on the right corresponds to the geologic map of the emerald deposits in Dayakou in figure 6.

were summarized, and some inclusions and accessory minerals were identified by Raman and XRD. Above all, micro UV-Vis-NIR, LA-ICP-MS, and EPR were used to investigate the chemical composition, optical absorption, and color features of Malipo emeralds.

\section{CULTURAL HERITAGE AND RESOURCE}

Malipo County is part of Wenshan Autonomous Prefecture, known for the cultural heritage of its minority ethnic groups. Two prominent ethnic groups, the Miao and the Zhuang, wear distinctive ethnic dress and sumptuous silver jewelry (http://m.visit ourchina.com/blog/detail-348.html). Numerous minority groups there have given birth to a rich and colorful culture that has been passed down from generation to generation. Wenshan Autonomous Prefecture's cultural heritage includes traditional folk literature, music, dance, art, architecture, crafts, and drama. In addition to this important cultural resource,

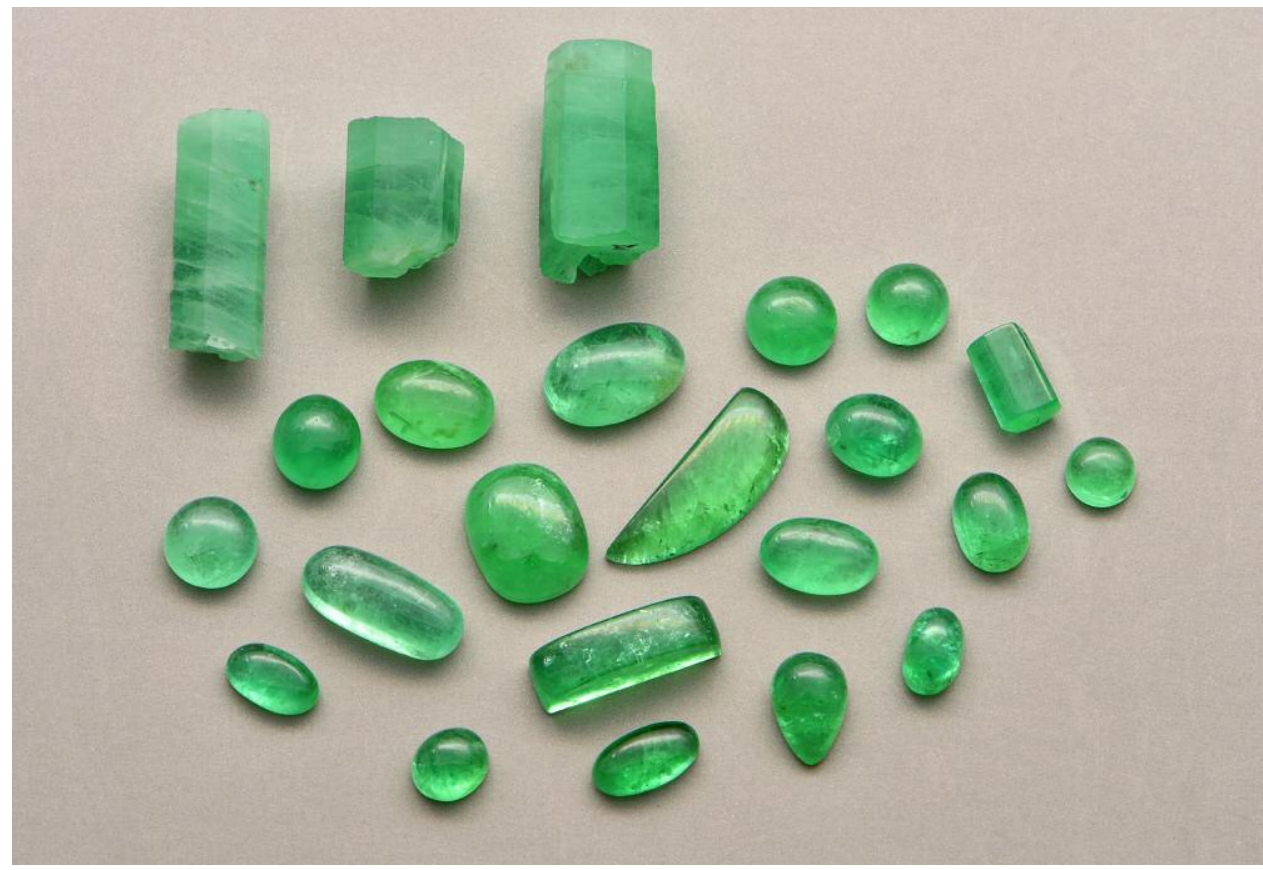

Figure 3. These gemquality rough and polished emeralds from Malipo, used in the present study, show medium to intense yellowish green color. The polished emeralds range from 0.20 to 1.00 ct and the rough crystals from 1.75 to 3.00 ct. Photo by Yang Hu. 


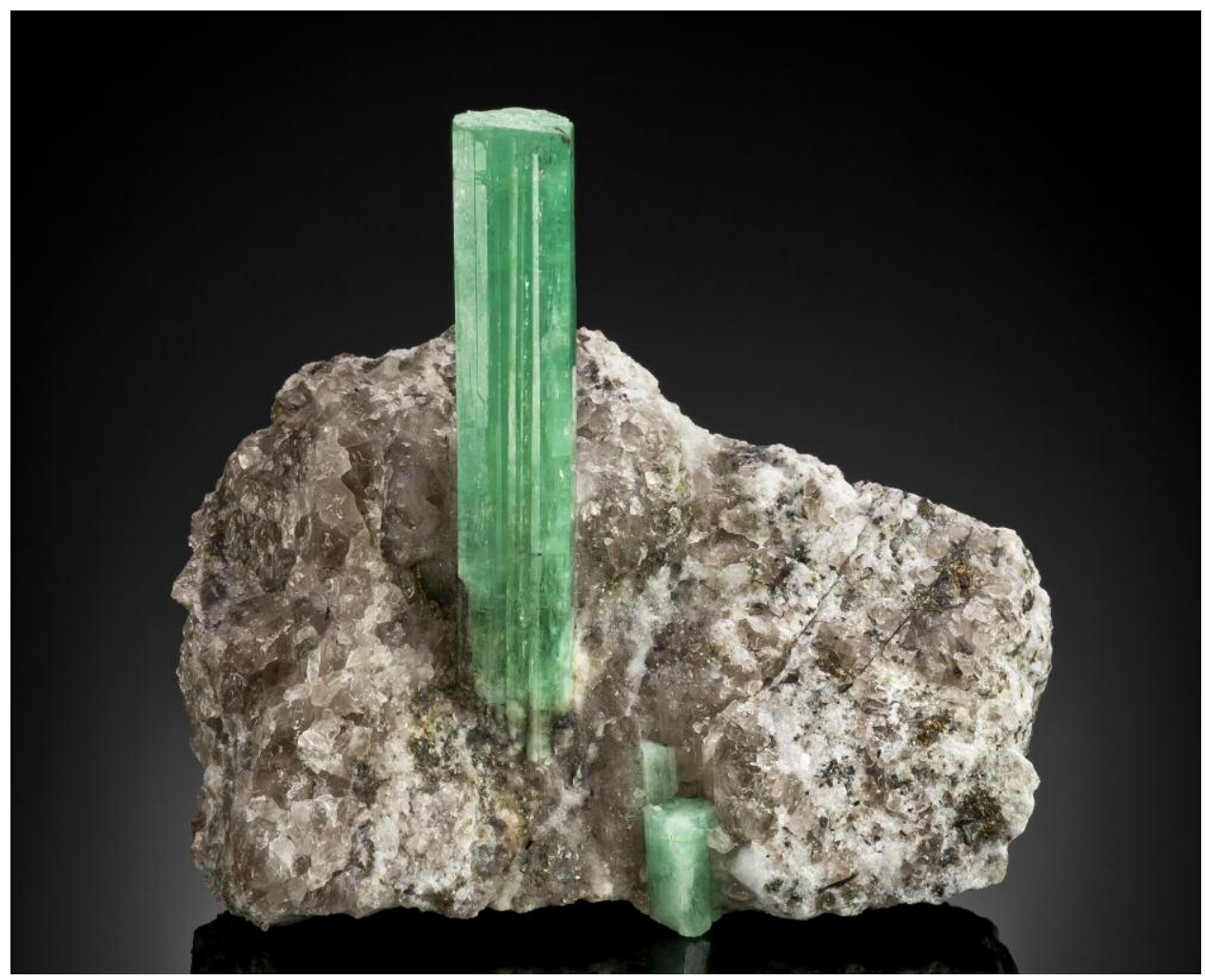

Figure 4. A collector's item, found in 2011, of emerald crystal specimens in matrix from the Dayakou mine in Malipo County, China. The longest emerald crystal measures about $93 \mathrm{~mm}$. The matrix mainly consists of quartz, feldspar, and dark muscovite. Courtesy of Arkenstone, Robert Lavinsky collection.

Malipo County is known for its rich ore resources, namely the strategically important metal tungsten. Significant tungsten deposits were first discovered in 1943 (Jin et al., 1943), and 23 occurrences were located by 2012 .

Emeralds were first discovered in the Malipo region in the late 1980s as associated minerals during tungsten mining. From 1996 to 1997, the regional geology and emerald resources in the area were systematically surveyed by the Yunnan Bureau of Geology and Mineral Resources. According to Wang et al. (1996), 22 pegmatites and 8 quartz veins related to emerald had been documented, with an estimated emerald reserve of about 7 tons.

Local villagers were collecting minerals and ore materials sporadically for years before government regulation. In 2009, the local government authorized a mining company to extract tungsten ore, and the associated emeralds were mined specifically from then on. Some of these emerald specimens have been acquired by domestic and international museums and private collectors (figure 4). At present, the tungsten mine is still in operation, and emeralds have also been produced in Dayakou (figure 5). But no emerald mining activity or production are reported officially by this government-authorized tungsten mining company.
With China's increasing awareness and interest in gems, the local government started to promote Malipo emerald as "Chinese emerald." Indeed, China's emerald industry is supported and protected by the local government. Public auctions for Malipo emeralds

\section{In Brief}

- Emeralds from Malipo County, in southwest China's Yunnan Province, occur in association with quartz and pegmatite veins and Proterozoic granofels.

- The Malipo emerald deposit has produced mineral specimens, traditional carvings, and cabochons.

- Abundant $\mathrm{V}^{3+}$ in octahedral coordination is the predominant chromophore, leading to a yellowish green color.

- A distinctive combination of high $\mathrm{V}$, low $\mathrm{Cr}$, and moderate Fe, as well as high $\mathrm{Li}$ and $\mathrm{Cs}$ concentrations, helps separate Malipo emerald from other deposits.

have been organized, and trading centers have been established. Moreover, gem and jewelry processing companies were created and introduced new techniques. Policies were enacted to protect emerald resources and to regulate the mining activity. 


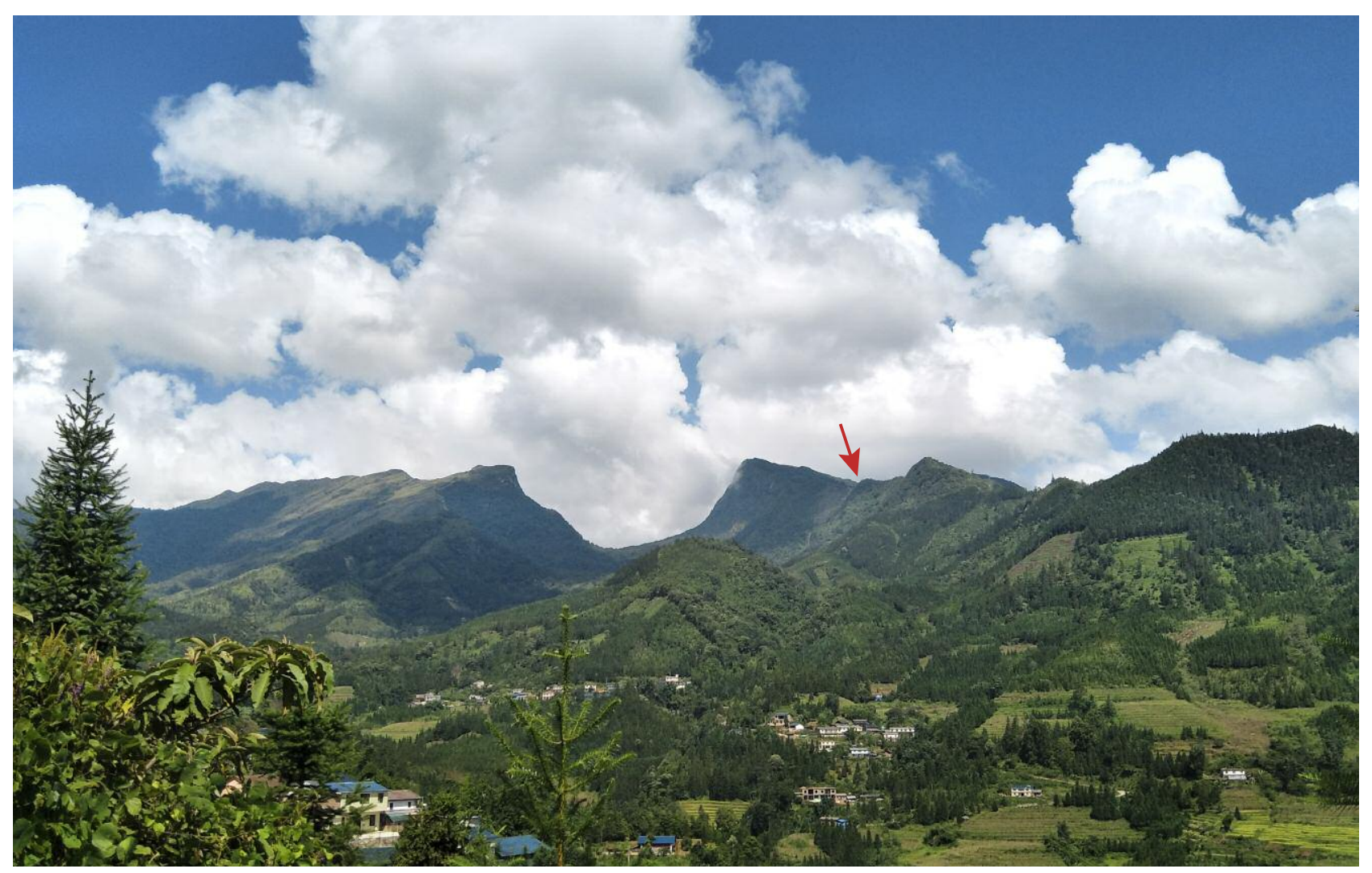

Figure 5. The Malipo emerald mine is located to the right of the middle mountain ridge, about 1,800 meters above sea level. Residences are located at the foot of the mountain. Photo by Daowen Ye.

\section{GEOLOGY}

The Dayakou emerald occurrence lies in the northern part of the Laojunshan-Song Chay metamorphic core complex (Zhang et al., 1999; Feng et al., 2000). The core complex covers an area of approximately 2,000 $\mathrm{km}^{2}$, and nearly one-third of that is in China. The Chinese counties of Malipo and Maguan and the Ha Giang Province of northern Vietnam are all in this area. The core complex is composed of a Proterozoic metamorphosed core and an upper cover of Paleozoic metasedimentary rocks (Zhang et al., 1998). The metamorphosed core consists of Silurian gneiss granites, Cretaceous porphyritic granites, and granitic to pegmatitic intrusions. Patches of the Proterozoic Mengdong succession are also situated locally within the core. The Mengdong succession consists of structurally layered metamorphic rocks: the basal Nanyangtian unit and the overlying Saxi unit (Zhang et al., 1999) (figure 6). The Nanyangtian unit is generally composed of schist. The Saxi unit is comprised of granofels, gneiss, amphibolites, and calcareous sedimentary rocks, with granofels as the main host rock for emerald mineralization at Dayakou (Xue et al., 2010).
Emerald at Dayakou generally occurs in northwest-southeast-trending quartz veins and northeastsouthwest-trending pegmatite veins intruding deformed Proterozoic granofels, gneiss, and schist of the Nanyangtian and overlying Saxi units (Xue et al., 2010) (figure 6). Some emeralds also mineralize in the contact zone with host rocks. Dozens of emeraldbearing pegmatite veins cover an area of $10 \mathrm{~km}^{2}$. The length of the ore body is between 20 and $280 \mathrm{~m}$, and the width is 0.2 to $1.5 \mathrm{~m}$. According to the classification of emerald type provided by Schwarz and Giuliani (2001), this is a granite-related emerald deposit (Groat et al., 2008).

In general, the emeralds that occur in the quartz veins at Dayakou are of better quality, with saturated green color and high transparency. In contrast, the emeralds within the pegmatite veins are larger, more abundant, and idiomorphic. Various associated minerals occur in emerald-bearing quartz and pegmatitic veins, such as potassic feldspar and mica, as well as minor scheelite, fluorite, calcite, tourmaline, and some sulfide assemblages (Zhang et al., 1999; Feng et al., 2000). 


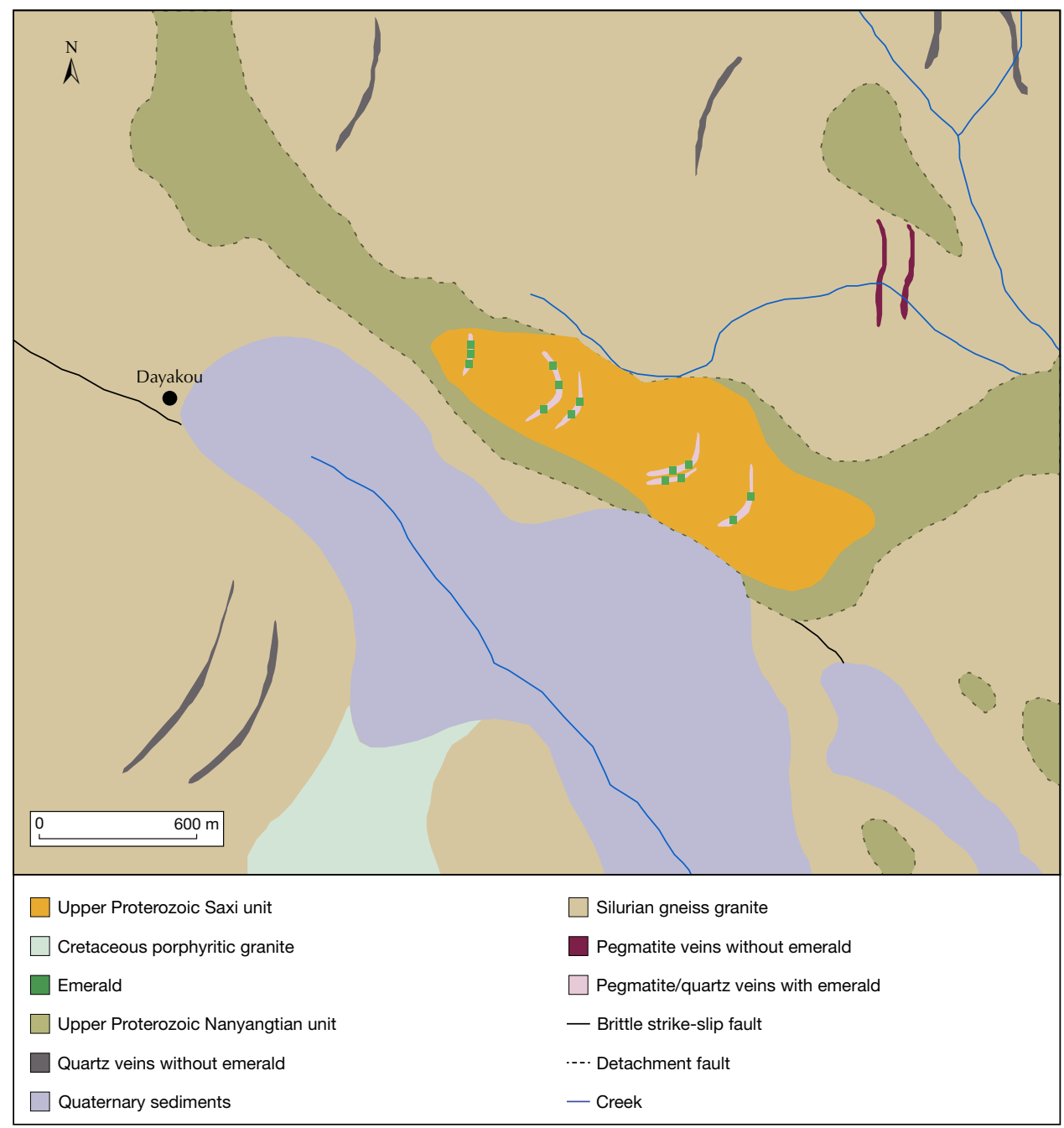

Figure 6. This simplified geologic map of the emerald deposit in Dayakou shows the distribution of major rock types and the main emerald occurrence. Modified from Wang et al. (1996).

\section{MATERIALS AND METHODS}

Twenty polished emeralds (figure 3), twenty-three rough crystals (three in figure 3 and twenty in figure 7), and three emerald-in-matrix specimens (one of them in figure 11) were gathered from local miners for this study. The miners extracted these samples privately in the area of the Dayakou emerald deposit. On average, the crystals measured a few centimeters in length, and the longest was $5 \mathrm{~cm}$ (figure 7). The cut emeralds ranged from 0.20 to $1.00 \mathrm{ct}$. Some crystals were contaminated by a brown material, possibly iron oxide, along the fractures and cavities.

All the emerald samples had been oiled by miners after extracting and/or polishing. Eight of the twenty rough samples in figure 7 were immersed in alcohol for two days to remove the oil before sample processing. Then they were fabricated as optical wafers (1.5$2 \mathrm{~mm}$ thick) oriented either perpendicular or parallel to the crystal's c-axis. In addition, the black matrix (see figure 11) was prepared as optical wafers to determine the associated minerals.

Gemological properties were measured on eight emerald wafers and twenty polished stones. Refractive indices and birefringence were obtained with a gem refractometer. UV fluorescence was examined under a UV lamp with long-wave $(365 \mathrm{~nm})$ and shortwave $(254 \mathrm{~nm})$ light in a darkened box. We also tested their reaction under the Chelsea filter. Dichroism was observed and photographed under a polarizing film. Specific gravity was determined by the hydrostatic method. The wafers' optical path length was measured using a digital caliper with an accuracy of 20 microns. Inclusions were observed and photographed at up to $256 \times$ magnification by a Leica M205A microscopic system equipped with brightfield and fiber-optic illumination as well as a polarizing attachment. 
Raman spectra were obtained with a Bruker Senterra R200 spectrometer coupled with a $532 \mathrm{~nm}$ laser to identify the associated mineral assemblages of the host rock and inclusions. The resolution was set at 5 $\mathrm{cm}^{-1}$, and the laser energy was $20 \mathrm{~mW}$. Two scans with $20 \mathrm{~s}$ integration time for each scan were taken for a single spectrum. Raman spectra from at least three spots on each sample were recorded to ensure the consistency of the data. X-ray powder diffraction (XRPD) was carried out on associated mineral assemblages from $3^{\circ}$ to $64^{\circ}$ on a PANalytical X'pert Pro diffractometer with $\mathrm{Cu}-\mathrm{K} \alpha$ radiation $(\lambda=1.5405 \AA$, 40 $\mathrm{kV}, 40 \mathrm{~mA})$, using a step size $(2 \theta)$ of $0.02^{\circ}$ and a step time of $0.15 \mathrm{~s}$ each.

Trace element contents of eight emerald wafers were analyzed by laser ablation-inductively coupled plasma-mass spectrometry (LA-LCP-MS) using an Agilent 7700 ICP-MS combined with a GeoLas $193 \mathrm{~nm}$ laser. We set the laser fluence at 9 $\mathrm{J} / \mathrm{cm}^{2}$ with a $6 \mathrm{~Hz}$ repetition rate and the laser spot size at $44 \mu \mathrm{m}$ diameter. Element concentrations were calibrated against multiple reference materials (BCR-2G, BHVO-2G, and BIR-1G) without using an internal standard (Liu et al., 2008), and Al was chosen as the normalizing element. Standard reference material NIST 610 glass was also applied to time-drift correction. Three laser spots for each sample were applied on a clean area with uniform yellowish green color, where UV-Vis-NIR spectra were also collected.

The absorption coefficients were calculated based on the Beer-Lambert Law with polarized ultraviolet/visible/near-infrared (UV-Vis-NIR) spectra of eight emerald wafers. These spectra were recorded by a Jasco MSV-5200 micro-spectrometer equipped with a microscope and a Glan-Taylor polarizer system over the range of 250-2500 $\mathrm{nm}$ with $1 \mathrm{~nm}$ bandwidth in the UV-Vis region and $8 \mathrm{~nm}$ bandwidth in the NIR region, at a scan speed of $200 \mathrm{~nm} / \mathrm{min}$. The optical aperture was set at $200 \mathrm{~nm}$ and $0.5 \mathrm{~nm}$ data interval. Both ordinary ray (o-ray) and extraordinary ray (e-ray) spectra were obtained for each sample. Electron paramagnetic resonance (EPR) spectroscopy was performed by a JEOL JES-FA200 EPR spectrometer at the $\mathrm{X}$-band $(9.1536 \mathrm{GHz}$ microwave frequency, $5 \mathrm{~mW}$ microwave power) with the crystal c-axis parallel and normal to the magnetic field $\mathrm{H}(\mathrm{H} \| \mathrm{c}$ and $\mathrm{H} \perp \mathrm{c})$ at room temperature (300K). Measurement parameters were set at 3200 Gauss center field, 5000 Gauss sweep width, $30 \mathrm{~s}$ sweep time, $0.03 \mathrm{~ms}$ time constant, and $100 \mathrm{kHz}$ modulation frequency.

\section{RESULTS}

Gemological Properties. The Malipo emeralds typically showed medium to intense yellowish green color. Color zoning was present in some crystals per-

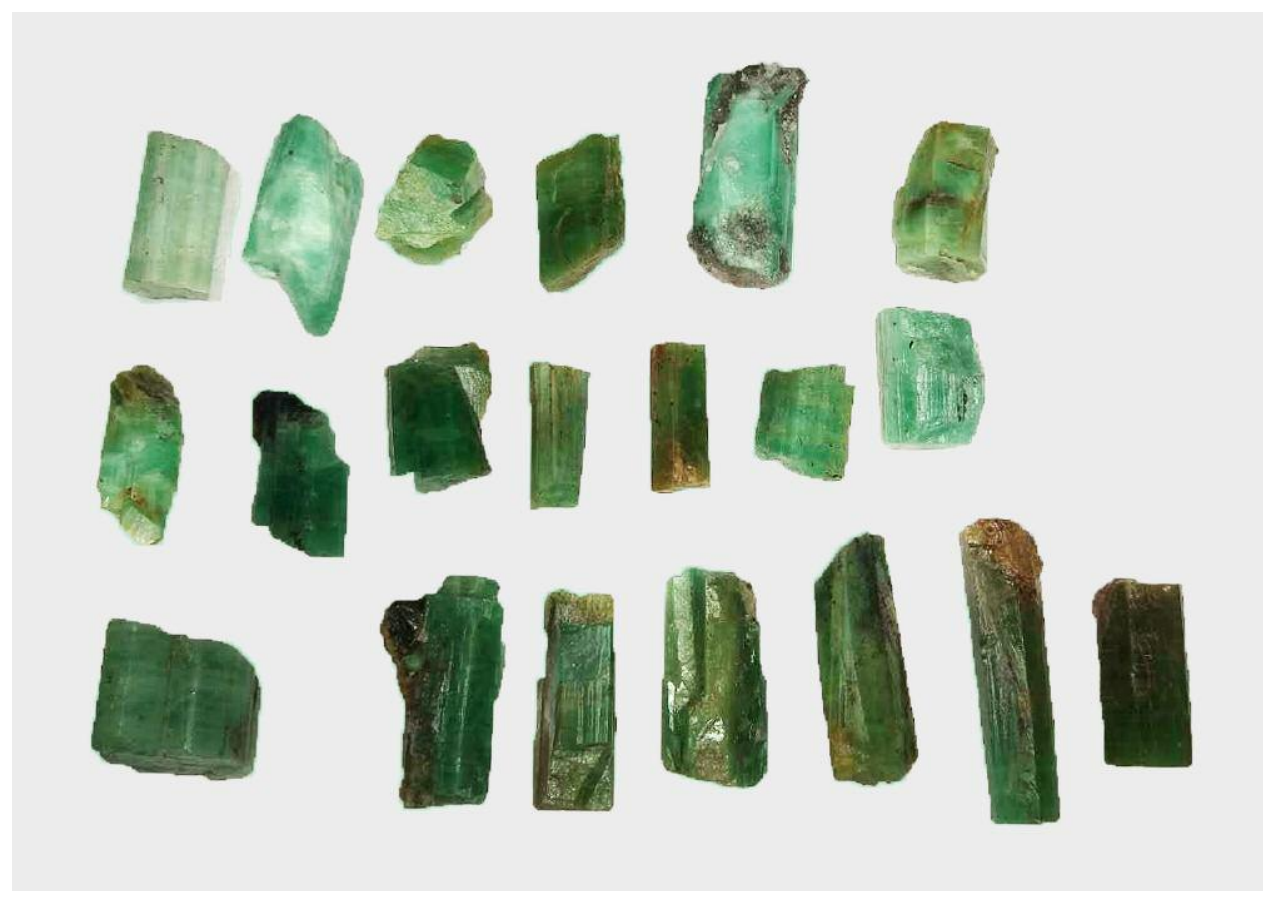

Figure 7. A group of medium- to low-quality rough Malipo emerald crystals were investigated in this study. Eight of them were processed as optical wafers for LA-ICP$M S, U V-V i s-N I R$, and EPR measurements, as well as for color zoning study. Associated minerals and brown contaminant were present on some crystals. The crystals shown here average a few centimeters in length. Photo by Yang Hu. 


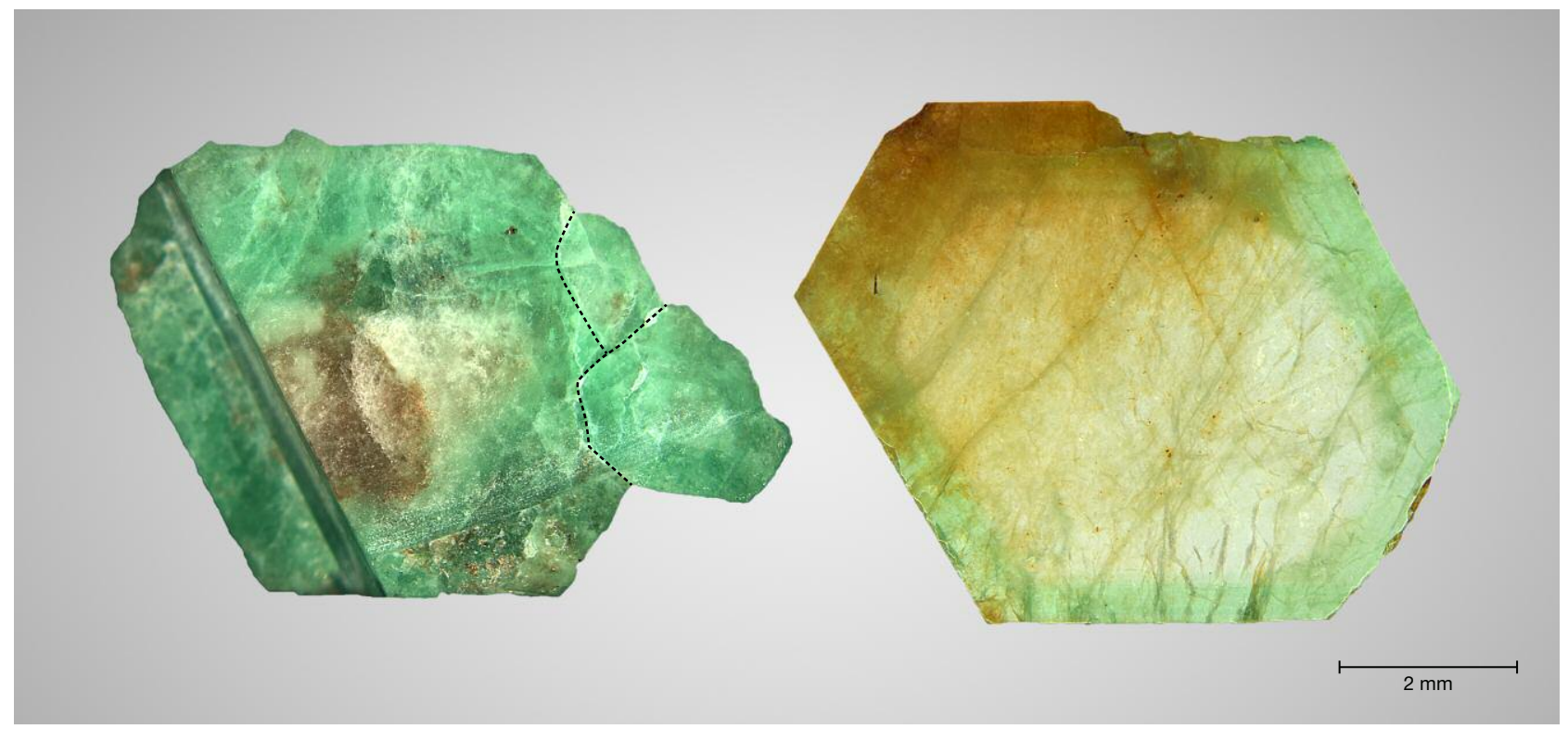

Figure 8. Color zoning in Malipo emerald crystals perpendicular to the c-axis ranges from a yellowish green rim to a colorless or white core. The sample on the left shows parallel intergrowth of at least three crystals (labeled by the black dotted line). Photo by Yang Hu.

pendicular to the c-axis, ranging from a yellowish green rim to a colorless core (figure 8). Some samples were near-transparent to translucent owing to the presence of fractures along and/or normal to the caxis. Parallel growth striations were seen on prismatic faces. In addition, we observed parallel intergrowth for some emerald crystals (e.g., the one on the left in figure 8).

The refractive indices varied from 1.576-1.582 for $\mathrm{n}_{\mathrm{e}}$ and 1.582-1.589 for $\mathrm{n}_{\mathrm{o}}$. Birefringence ranged from 0.006 to 0.008 . Specific gravity was 2.66-2.71. Malipo emerald had no reaction under the Chelsea filter. No fluorescence was shown under either long-wave or short-wave UV. Under a polarizing film, bluish green could be observed along the e-ray and yellowish green along the o-ray.

Microscopic Characteristics. Two-phase inclusions with a gas bubble suspended in fluid were the most common inclusion in Malipo emeralds (figure 9). These two-phase inclusions were several to hundreds of microns long, and the width ranged from several to tens of microns. The inclusions displayed various shapes: rectangular, rod-like, needle-like, jagged, and oval or some irregular shapes. The gas bubble usually occupied less than one-third of the volume of the cavity hosting the two-phase inclusion at room tem- perature. Gas bubbles were sometimes deformed and flattened owing to the outline of the two-phase inclusions. The hosted gaseous phase was identified by Raman spectra as $\mathrm{CO}_{2}$ and $\mathrm{N}_{2}$. In addition, dense growth tubes oriented parallel to the c-axis were present in some samples.

Occasionally, a colorless transparent crystal was observed in the multiphase inclusions (figure 10). When observed, these crystals were slightly smaller than the accompanying gas bubbles. The outline of the crystals was near-cubic or irregular, and they were absent in adjacent multiphase inclusions of the same mineralization period. They were somewhat different from the common cubic halite in multiphase inclusions. It was also difficult to determine if they were singly or doubly refractive under cross-polarized illumination. Therefore, we could not confirm whether the crystal was halite, or beryl itself, or other minerals. Huang et al. (2017) determined the presence of halite in Malipo emeralds based only on the oval outline of the crystal. Thus far, no specific evidence of halite in multiphase inclusions has been confirmed in Malipo emeralds.

Various associated minerals were identified by Raman spectra and XRPD in the host rock of our samples, including microcline, calcite, quartz, tourmaline (likely foitite), fluorite, phlogopite, pale yel- 

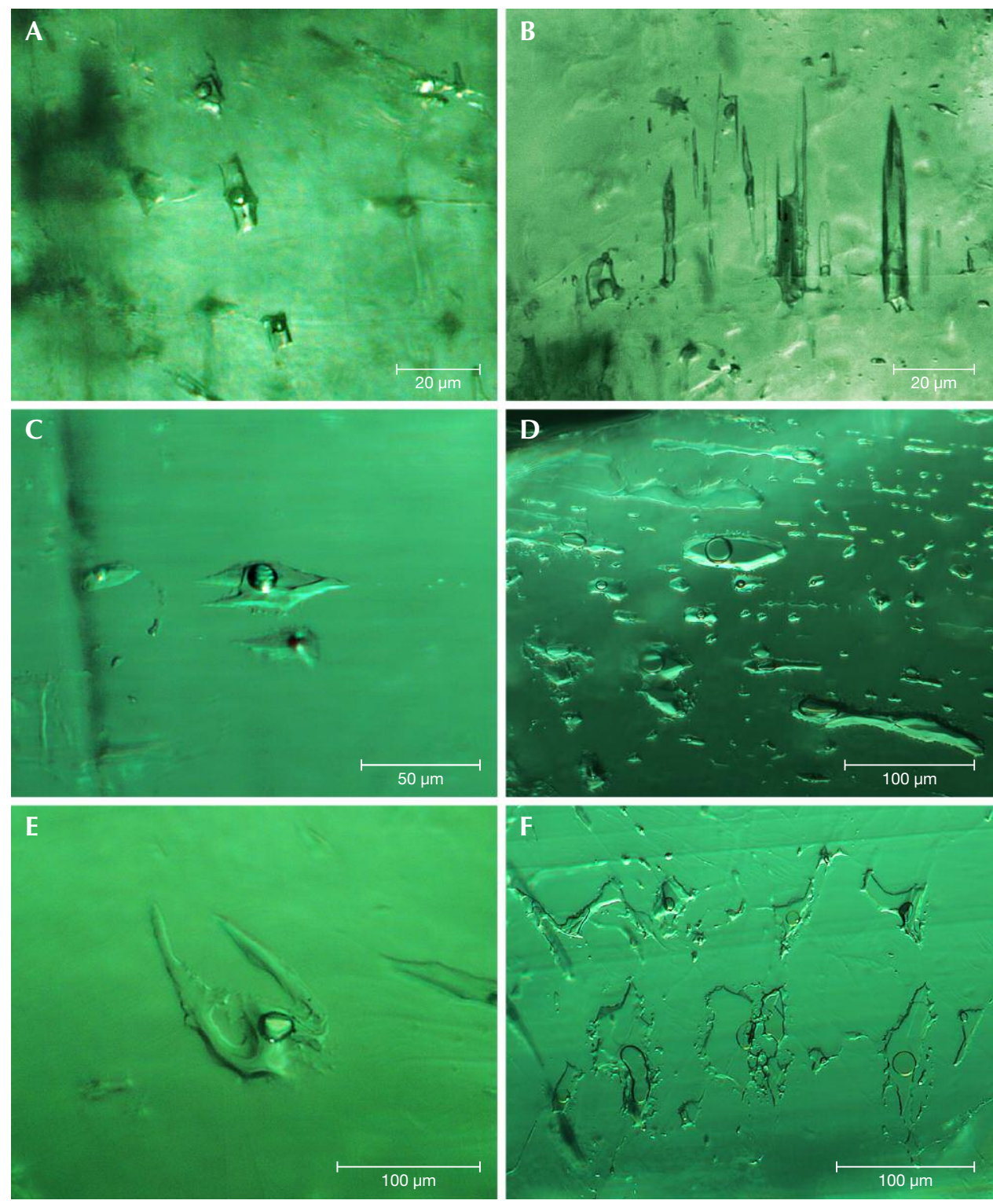

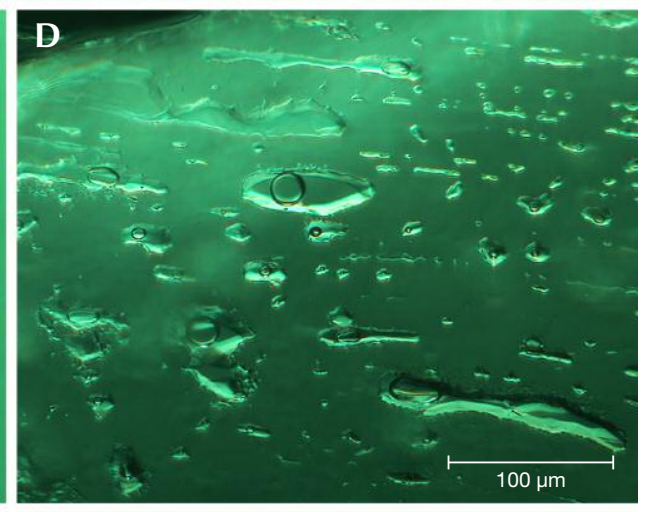

D
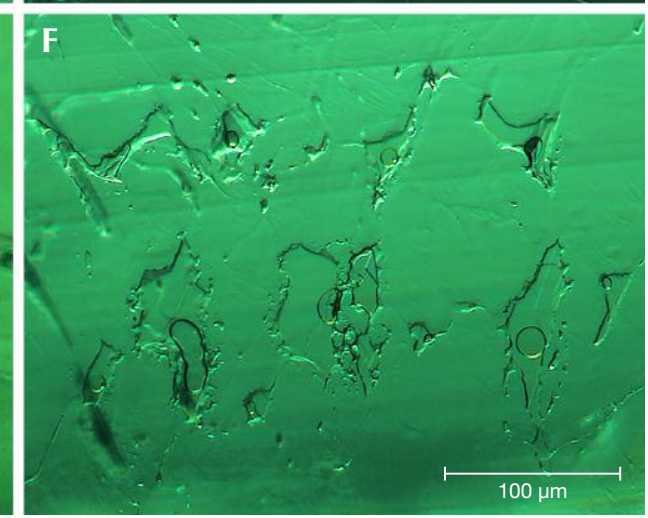

Figure 9. Variously shaped two-phase inclusions in Malipo emeralds. A: Rectangular two-phase inclusions containing round gas bubbles. B: Needlelike two-phase inclusions hosting small gas bubbles. C: A jagged two-phase inclusion with a round gas bubble inside. D: Rod-like and oval two-phase inclusions parallel to the $c$-axis. E and F: Irregular two-phase inclusions hosting round or deformed bubbles. Photomicrographs by Yang $\mathrm{Hu}$, brightfield illumination. low scheelite, and pyrrhotite (figure 11). Scheelite is an especially significant ore mineral for extracting tungsten in the nearby Dayakou tungsten mine. It displayed pale orange color, octahedral shape, and strong bluish fluorescence under short-wave UV. Some of these associated minerals were sometimes seen in Malipo emeralds as single-phase inclusions.

Trace Element Analysis. Eight Malipo emerald wafers were analyzed by LA-ICP-MS, and the results are shown in table 1 . Concentrations of alkali metals ranged from highest content to lowest as follows: $\mathrm{Na}$ 6003-9481 ppmw (averaging 7524 ppmw), Cs 17302560 ppmw (averaging 2087 ppmw), Li 259-350 ppmw (averaging 306 ppmw), K 83-301 ppmw (aver- aging 155 ppmw), and $\mathrm{Rb} 18-32$ ppmw (averaging 25 ppmw). Total alkali element concentrations including $\mathrm{Li}, \mathrm{Na}, \mathrm{K}, \mathrm{Rb}$, and Cs ranged from 8318 to 12403 ppmw. Malipo emerald also contained a significant amount of $\mathrm{Mg}$ (3941-7406 ppmw), and trace amounts of Sc (71-168 ppmw), Zn (17-187 ppmw), and Ga (1215 ppmw).

The emerald samples contained abundant transition element V from 966 to 4568 ppmw, averaging 3473 ppmw, and a lower amount of $\mathrm{Cr}$ (3-870 ppmw, averaging $186 \mathrm{ppmw}$ ). Chromium content was as low as 3 ppmw in sample E4. The ratio of $\mathrm{Cr}$ to $\mathrm{V}$ was between 0.001 and 0.20 . Iron content varied in a relatively narrow range from 2519 to 3770 ppmw and averaged 3474 ppmw. Trace amounts of Mn (averag- 

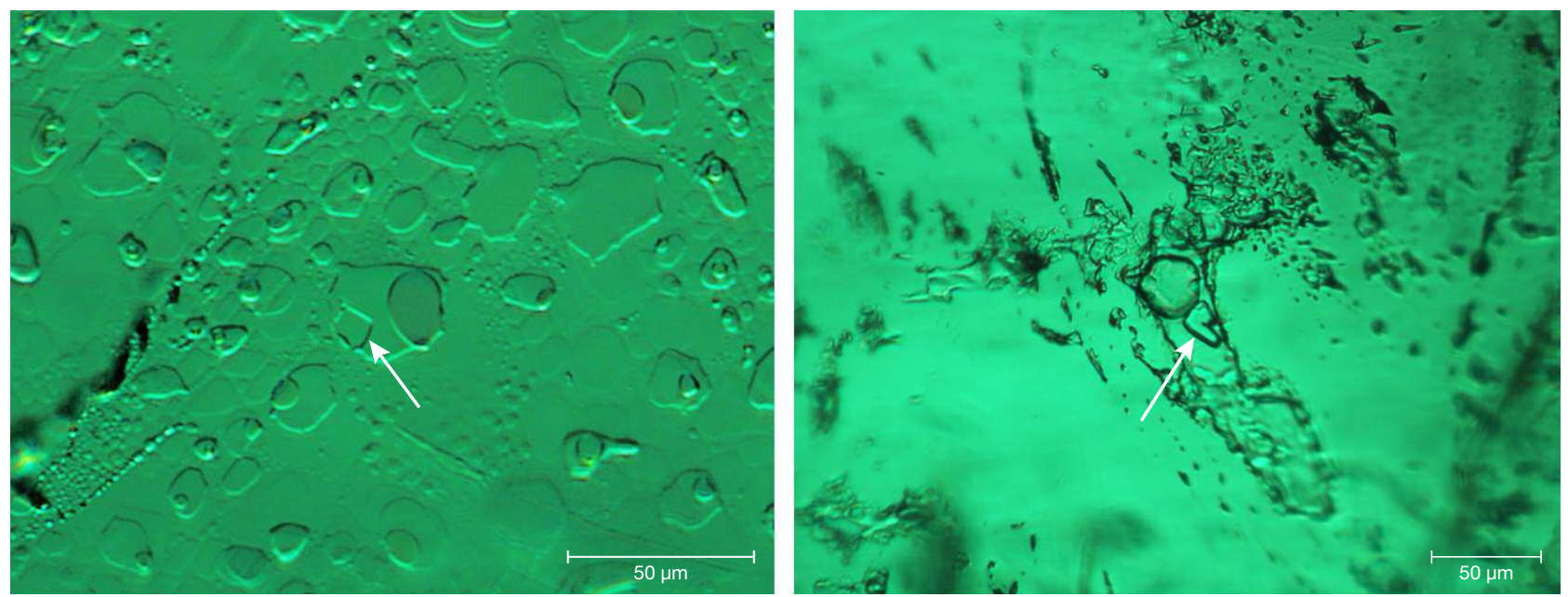

Figure 10. Three-phase inclusions in Malipo emeralds, shown in brightfield illumination. Colorless transparent crystals with near-cubic (left) or irregular shape (right) were visible (indicated by the arrows), along with oval to near-round gas bubbles in the blocky and irregular multiphase inclusions. Photomicrographs by Yang Hu.

ing $70 \mathrm{ppmw}$ ) were also detected. It is worth noting that the low $\mathrm{Cr}$ concentrations listed in table 1 were all detected from yellowish green zones instead of colorless zones. The low $\mathrm{Cr}$ content and the presence

Figure 11. An emerald-in-matrix hand specimen associated with microcline, quartz, pale yellow scheelite, phlogopite, and pyrrhotite. Photo by Yang Hu.

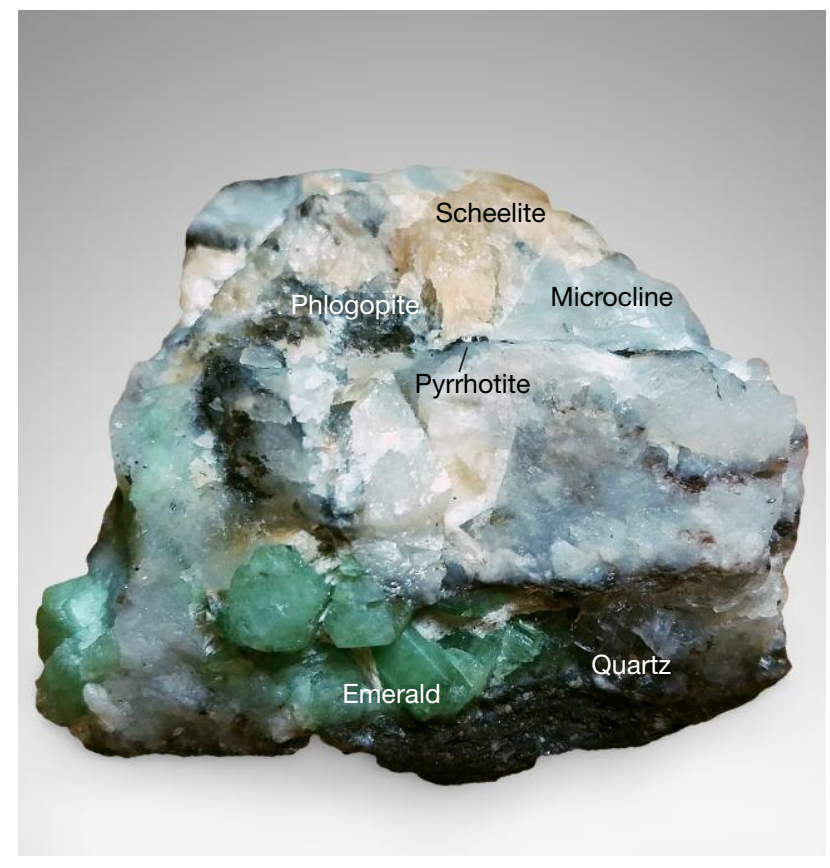

of Fe could be responsible for the lack of UV fluorescence in Malipo emeralds.

UV-Vis-NIR Spectroscopy. Representative UV-VisNIR spectra of Malipo emerald samples showed quantitative information on chromophoric absorption $(250-1100 \mathrm{~nm})$ and water molecular vibrations (900-2500 nm); see figure 12. Relative contributions from all absorption features are readily compared across the whole spectral range.

The region of chromophoric absorption (250-1100 $\mathrm{nm}$ ) showed the main absorption of trivalent vanadium ions. Two absorption maxima at 432 and 611 $\mathrm{nm}$ (o-ray) and 425 and $644 \mathrm{~nm}$ (e-ray), as well as an absorption shoulder at $395 \mathrm{~nm}$ for the o-ray and e-ray in sample E7, were assigned to $\mathrm{V}^{3+}$ ions, according to the absorption of vanadium-doped synthetic emerald (Schmetzer et al., 2006). This absorption assignment was in agreement with our EPR result, theoretical crystal field energy levels of $\mathrm{V}^{3+}$ in beryl (Beckwith and Troup, 1973; Schmetzer et al., 1978), and distinctly higher vanadium content in Malipo emerald. These absorptions of $\mathrm{V}^{3+}$ were prominent in all of our emerald samples.

The anisotropic absorption of $\mathrm{V}^{3+}$ at $425-432 \mathrm{~nm}$ was obvious. The maximum absorption coefficient at $425-432 \mathrm{~nm}$ in the o-ray was nearly twice as high as in the e-ray. In addition, a weak shoulder centered at $675 \mathrm{~nm}$ was present for the o-ray. It was not a sharp line and obvious in the o-ray, distinguished 
TABLE 1. Chemical composition (in ppmw) of eight Malipo emeralds, obtained by LA-ICP-MS.

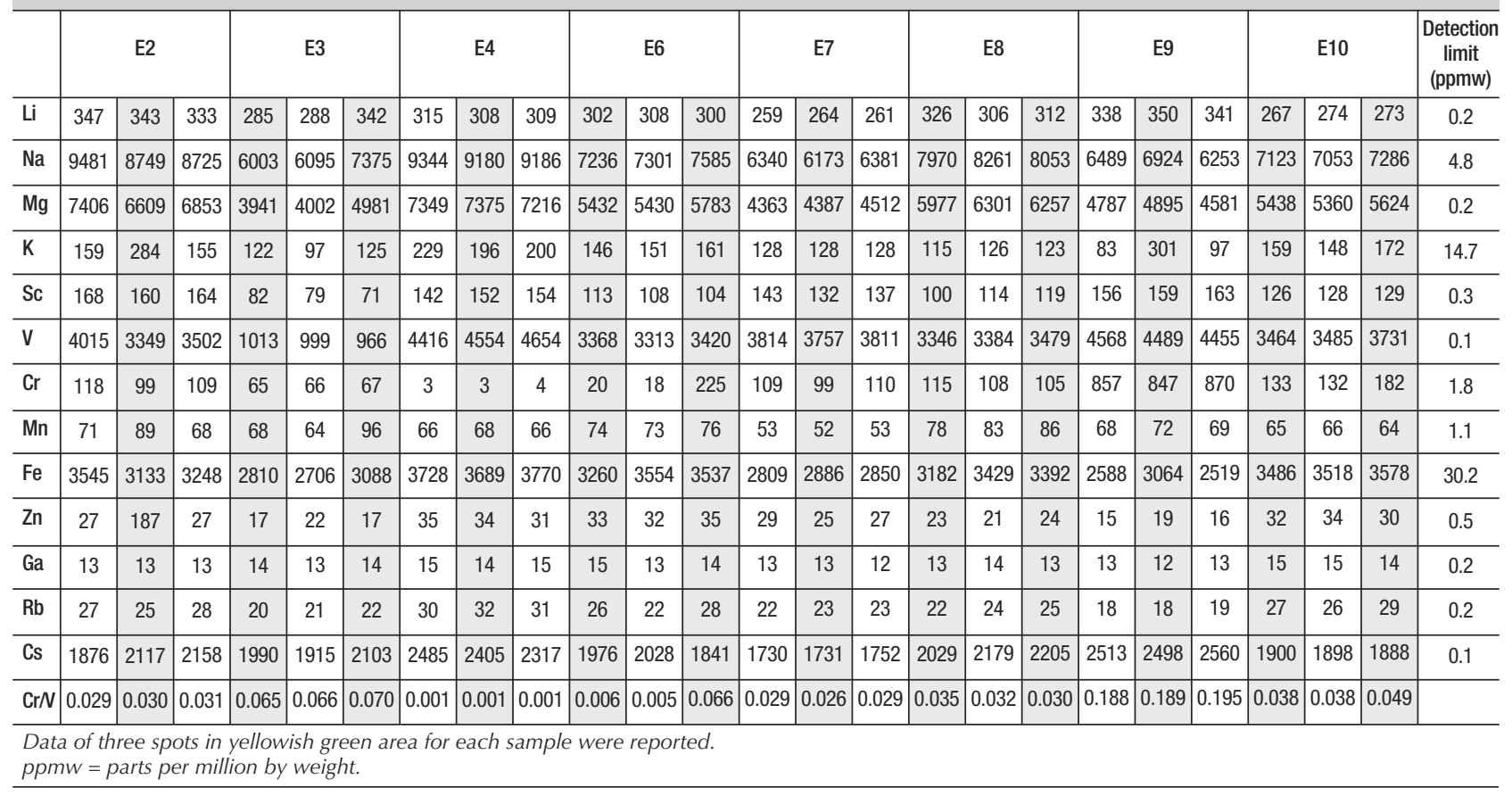

from $R$ lines of $\mathrm{Cr}^{3+}$. This shoulder was also shown in emerald sample E4, which had almost no $\mathrm{Cr}$ (3-4 ppmw). Therefore, this $675 \mathrm{~nm}$ shoulder should also be attributed to vanadium ions.

A moderate $830 \mathrm{~nm}$ absorption band was present for the o-ray of sample E7. This band has usually been attributed to specific $\mathrm{Fe}^{2+}$ ions (Wood and Nassau, 1968). All other emerald samples showed a similar $830 \mathrm{~nm}$ band height and an absorption coefficient unit no higher than $4 \mathrm{~cm}^{-1}$, consistent with the narrow range of Fe content (2519 to $3770 \mathrm{ppmw}$ ). This band height range was typical for Malipo emeralds.

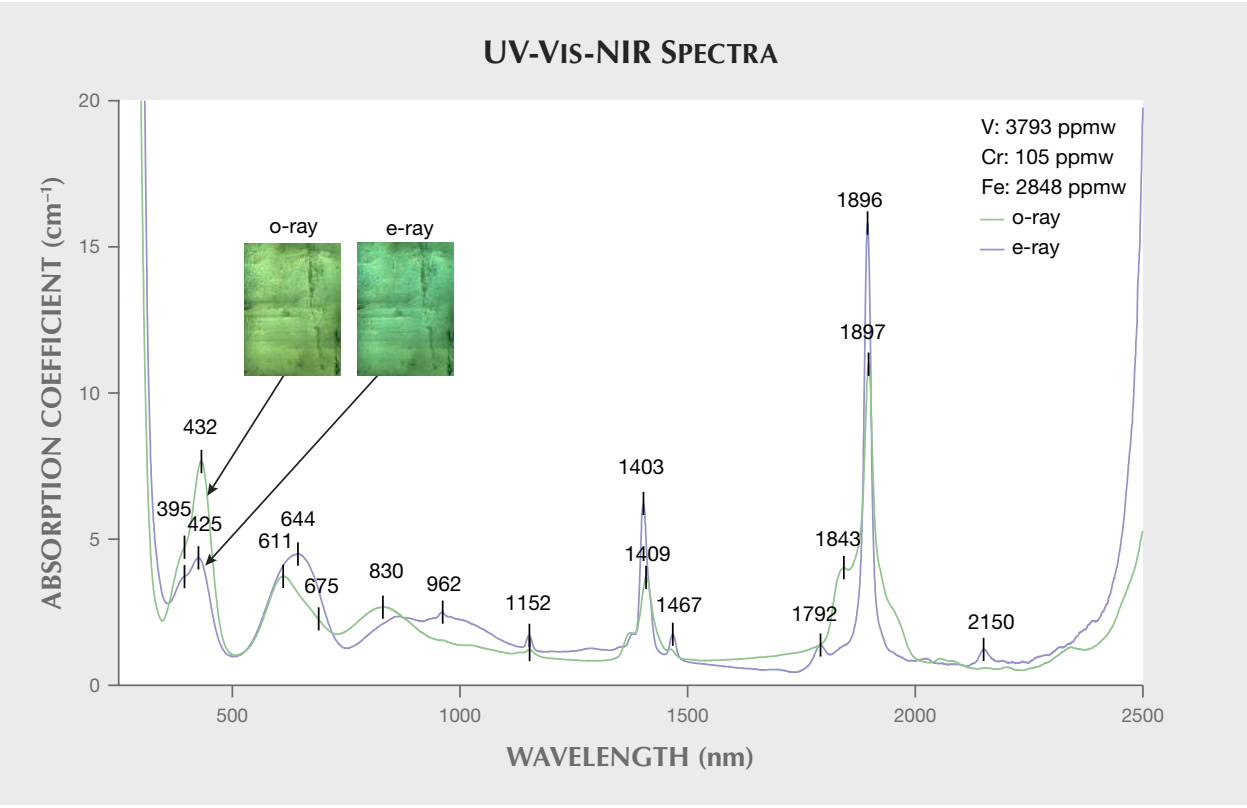

Figure 12. Representative UV-Vis-NIR spectra of sample E7. In the region of chromophoric absorption, it shows intense $V^{3+}$ absorption (432 and $611 \mathrm{~nm}$ for the o-ray, 425 and $644 \mathrm{~nm}$ for the e-ray, and a $395 \mathrm{~nm}$ shoulder for the $o$ - and $e$ rays) and moderate $\mathrm{Fe}^{2+} \mathrm{ab}$ sorption $(830 \mathrm{~nm}$ for the o-ray). Type I water absorption is shown at 1897, 1896, 1792, 1467, and $1403 \mathrm{~nm}$. The inset photos display obvious dichroism: a yellowish green color for the o-ray and a bluish green color for the e-ray. Chromophore element contents of sample E7 are shown on the top right. 
No other Fe-related absorption was observed in any of the samples, such as the band centered at $620 \mathrm{~nm}$ or the 427 and $372 \mathrm{~nm}$ peaks seen in emeralds from other localities.

Weak $\mathrm{Cr}^{3+}$ absorption was sometimes accompanied by absorptions of $\mathrm{V}^{3+}$ and $\mathrm{Fe}^{2+}$ ions in the samples. According to Wood and Nassau (1968), $\mathrm{Cr}^{3+}$ in emerald could lead to the main absorption bands at approximately 430 and $600 \mathrm{~nm}$ for the o-ray and 420 and $630 \mathrm{~nm}$ for the e-ray. These absorption bands were superimposed over those of vanadium ions, but a series of weak peaks at 658,646 , and $637 \mathrm{~nm}$ and sharp $R$ lines at 680/683 nm were distinctive for $\mathrm{Cr}^{3+}$ in emerald, especially for the e-ray. Absorption of $\mathrm{Cr}^{3+}$ ions was not observed for the low $\mathrm{Cr}$ content (105 ppmw) in sample E7. But other Malipo emerald samples with slightly higher $\mathrm{Cr}$ content displayed a series of weak peaks $(658,646$, and $637 \mathrm{~nm})$ and $R$ lines, such as sample E9, which averaged $858 \mathrm{ppmw}$ Cr. Specifically, 680/683 nm $R$ lines were superimposed on the broad $\mathrm{V}^{3+}$ shoulder centered at $675 \mathrm{~nm}$ for the o-ray.

In the region of water molecular vibrations $(900-$ $2500 \mathrm{~nm}$ ), Malipo emerald showed absorption of type I water molecules. Water molecules in beryl occur in two configurations in structural channels called "type I" and "type II" (Wood and Nassau, 1967). Peaks between 1100 and $2500 \mathrm{~nm}$ were attributed to the overtone and combination vibrations of type I and/or type II water molecules. Strong peaks at 1897 $\mathrm{nm}\left(5271 \mathrm{~cm}^{-1}\right), 1896 \mathrm{~nm}\left(5274 \mathrm{~cm}^{-1}\right)$, and $1403 \mathrm{~nm}$ $\left(7127 \mathrm{~cm}^{-1}\right)$, as well as weak peaks at $1792 \mathrm{~nm}(5580$ $\left.\mathrm{cm}^{-1}\right)$ and $1467 \mathrm{~nm}\left(6816 \mathrm{~cm}^{-1}\right)$, were displayed for all the samples (figure 12), and these peaks were assigned to type I water (Wood and Nassau, 1967). So Malipo emeralds were dominated by type I water, the same as most emeralds from other major sources except Kafubu, Zambia (Saeseaw et al., 2014). Sodium ions interacted with adjacent type II water molecules in the channels, and the low content of type II water was in agreement with the low Na content in Malipo emeralds.

EPR Spectra. Electron paramagnetic resonance (EPR) is an electron absorption technique using magnetic fields to measure transition energy of impurity elements, radicals, or defects with unpaired electrons. EPR spectra can provide useful information for transition metal impurities on valence, ion occupation, site symmetry, and pair arrangements in crystals.

For the EPR of Malipo emeralds (figure 13), the signal of transition metal impurities differed greatly, with the c-axis either parallel to the magnetic field $\mathrm{H}(\mathrm{H} \| \mathrm{c})$ or normal to the magnetic field $\mathrm{H}(\mathrm{H} \perp \mathrm{c})$. Two strong peaks were detected at $\mathrm{g}=2.866$ and $\mathrm{g}=$ 1.968 in orientation $\mathrm{H} \| \mathrm{c}$. Peaks centered at $\mathrm{g}=1.968$ and their side peaks were assigned to $\mathrm{Cr}^{3+}$ ions. Because of the large zero-field splitting of $\mathrm{Cr}^{3+}$ ions, only one set of EPR (transition from $\mathrm{m}_{\mathrm{s}}=+1 / 2$ to $-1 / 2$ ) could be seen in the X-band (Ohkura et al., 1987). This $\mathrm{Cr}^{3+}$ center may also be overlapped by $\mathrm{Fe}^{3+}$ ionrelated centers for similar $\mathrm{g}$ factors. The assignment of the peak at $g=2.866$ was uncertain. In orientation $\mathrm{H} \perp \mathrm{c}$, the characteristic six-fold hyperfine structure of $\mathrm{Mn}^{2+}\left(\mathrm{m}_{\mathrm{s}}=+1 / 2\right.$ to $\left.-1 / 2\right)$ was shown (Gaite et al., 2001). The peak at $g=3.893$ probably arose from the $\mathrm{Fe}^{3+}$ ion (Lin et al., 2013).

The super-hyperfine structure of $\mathrm{V}^{2+}$ and $\mathrm{V}^{4+}$ in the form of vanadyl ions $\left(\mathrm{VO}^{2+}\right)$ was previously detected in Australian emerald and Biron gamma-irradiated vanadium-doped synthetic emerald by X-band EPR at room temperature (Hutton et al., 1991). But we were unable to detect any obvious EPR signal of $\mathrm{V}^{2+}$ or $\mathrm{V}^{4+}$, indicating that the abundant vanadium detected in Malipo emerald should be in another valence state. Vanadium in minerals is usually present in the valence of +3 and +4 (Rossman, 2014). $\mathrm{V}^{3+}\left(3 \mathrm{~d}^{2}\right)$ was hardly detectable by room temperature X-band EPR due to outer paired electrons. Thus, we concluded that nearly all vanadium in Malipo emerald was in the trivalent state.

Figure 13. EPR spectra of Malipo emerald E7 showed signals of $\mathrm{Cr}^{3+}, \mathrm{Mn}^{2+}$, and possibly the $\mathrm{Fe}^{3+}$ center, and no indications of any vanadium signal measured at $300 \mathrm{~K}$.

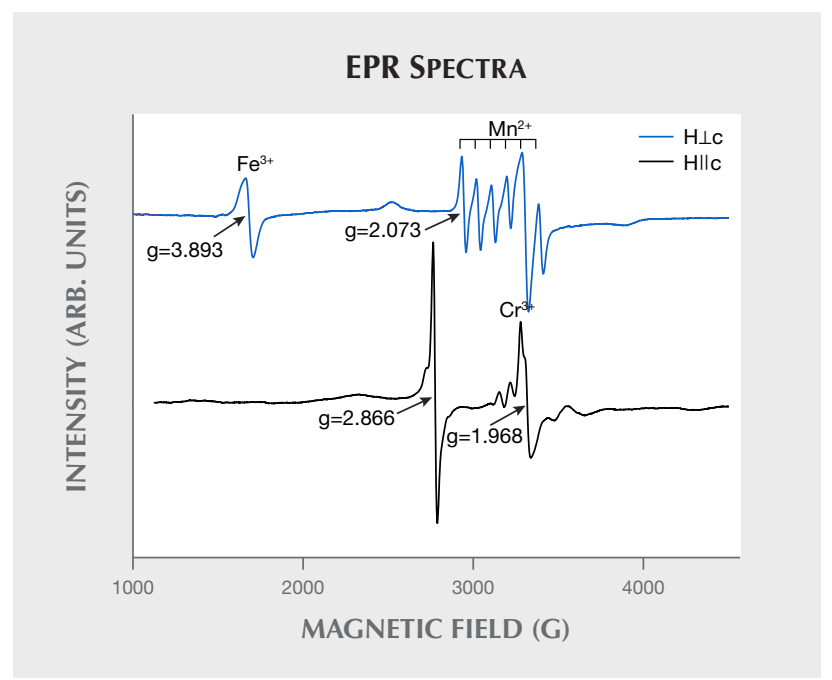




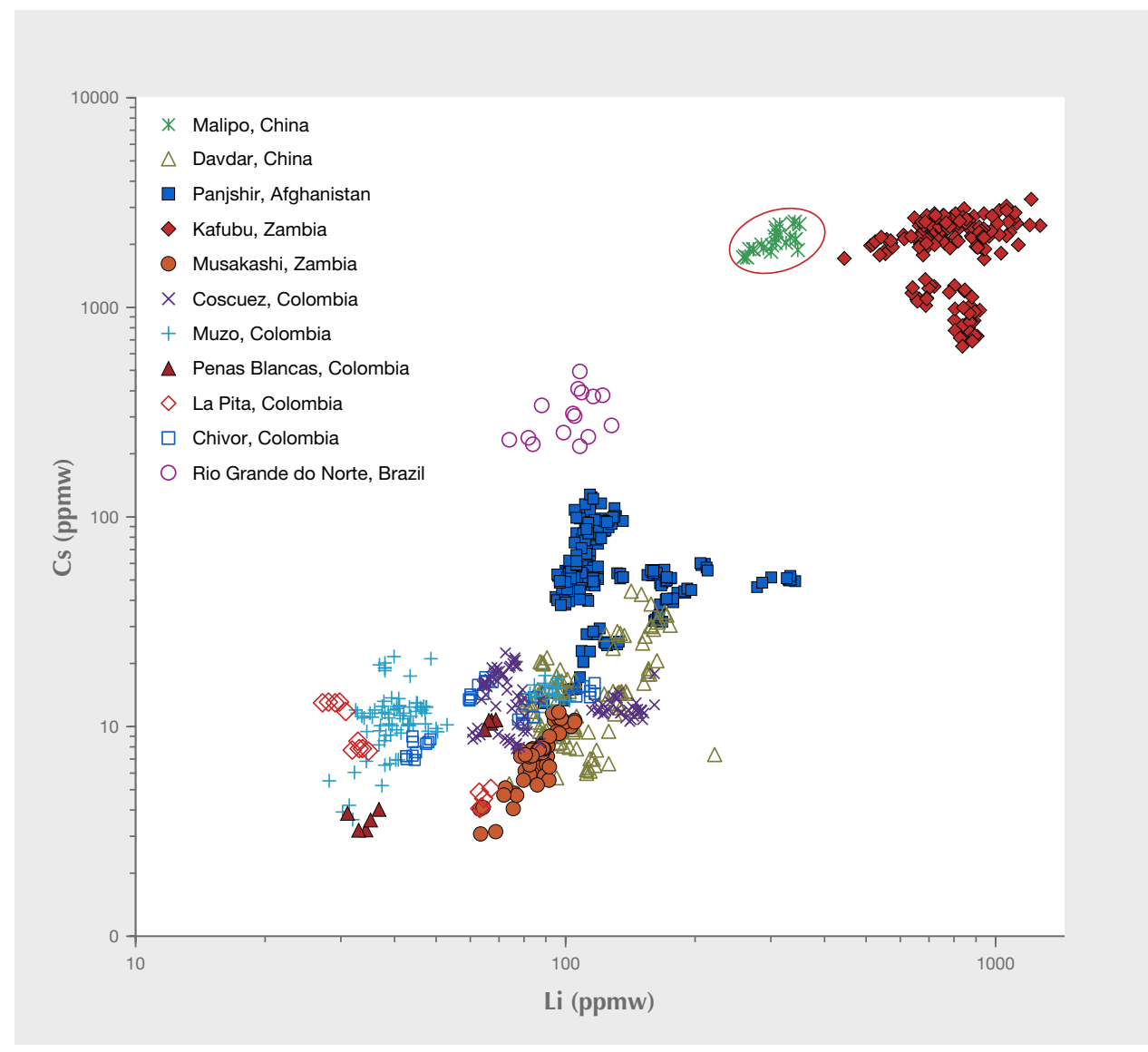

Figure 14. Malipo emeralds contained high concentrations of $\mathrm{Li}$ and Cs (within the red oval) and a unique ratio of Li to Cs among significant deposits. Other sources are from Saeseaw et al. (2014).

\section{DISCUSSION}

Multiphase Inclusions. The multiphase inclusion scene in Malipo emerald was quite distinct from that of other deposits investigated by Saeseaw et al. (2014). First, the multiphase inclusions in Malipo emerald were relatively small, less than two hundred microns in length and width. Second, multiphase inclusions in Malipo emerald displayed rectangular, rod-like, needle-like, jagged, and other irregular shapes. The rectangular multiphase inclusions were similar to those of emerald from Kafubu, Zambia. Elongated needle-like multiphase inclusions somewhat resembled those in emerald from Panjshir Valley, Afghanistan. Jagged multiphase inclusions resembled classic jagged multiphase inclusions in Colombian emeralds. Moreover, the crystal phase as part of a multiphase inclusion was occasionally observed in our samples. But emeralds from Kafubu, Panjshir, and Colombia usually host one or more crystals.

Trace Element Analysis. Malipo emeralds contained large amounts of $\mathrm{Li}$ and $\mathrm{Cs}$, and the ratio of $\mathrm{Cs}$ to $\mathrm{Li}$ distinguished them from emeralds of all other signif- icant localities. Li concentration in our emerald samples was relatively high (259-350 ppmw), just below that of Kafubu, Zambia, despite a slight overlap with emeralds from Panjshir, Afghanistan (see figure 14). Meanwhile, Cs concentration was the highest (17302560 ppmw) among all other deposits except Kafubu, which has a similar range of Cs content. Therefore, the ratio of Cs to Li was exclusively separate from other significant deposits. Concentrations of other alkali elements ( $\mathrm{Na}, \mathrm{K}$, and $\mathrm{Rb})$ and $\mathrm{Mg}$, Sc, $\mathrm{Zn}$, and Ga were low to moderate in Malipo emeralds, and more or less overlapped with those from some other deposits.

The combination of high $\mathrm{V}$, low $\mathrm{Cr}$, and moderate Fe content was distinctive for Malipo emeralds, as seen in the $\mathrm{Fe}-\mathrm{Cr}-\mathrm{V}$ ternary diagram in figure $15 . \mathrm{V}$ content was relatively high (averaging $3473 \mathrm{ppmw}$ ), just below some emeralds from Colombia and Norway, behaving as the most significant chromophore element in Malipo emerald. Meanwhile, Cr content was extremely low (averaging $186 \mathrm{ppmw}$ ) and similar to emeralds from Lened, Canada, and Gandao, Pakistan. Fe concentration was medium (averaging 3474 ppmw), in the same range as emeralds from many lo- 


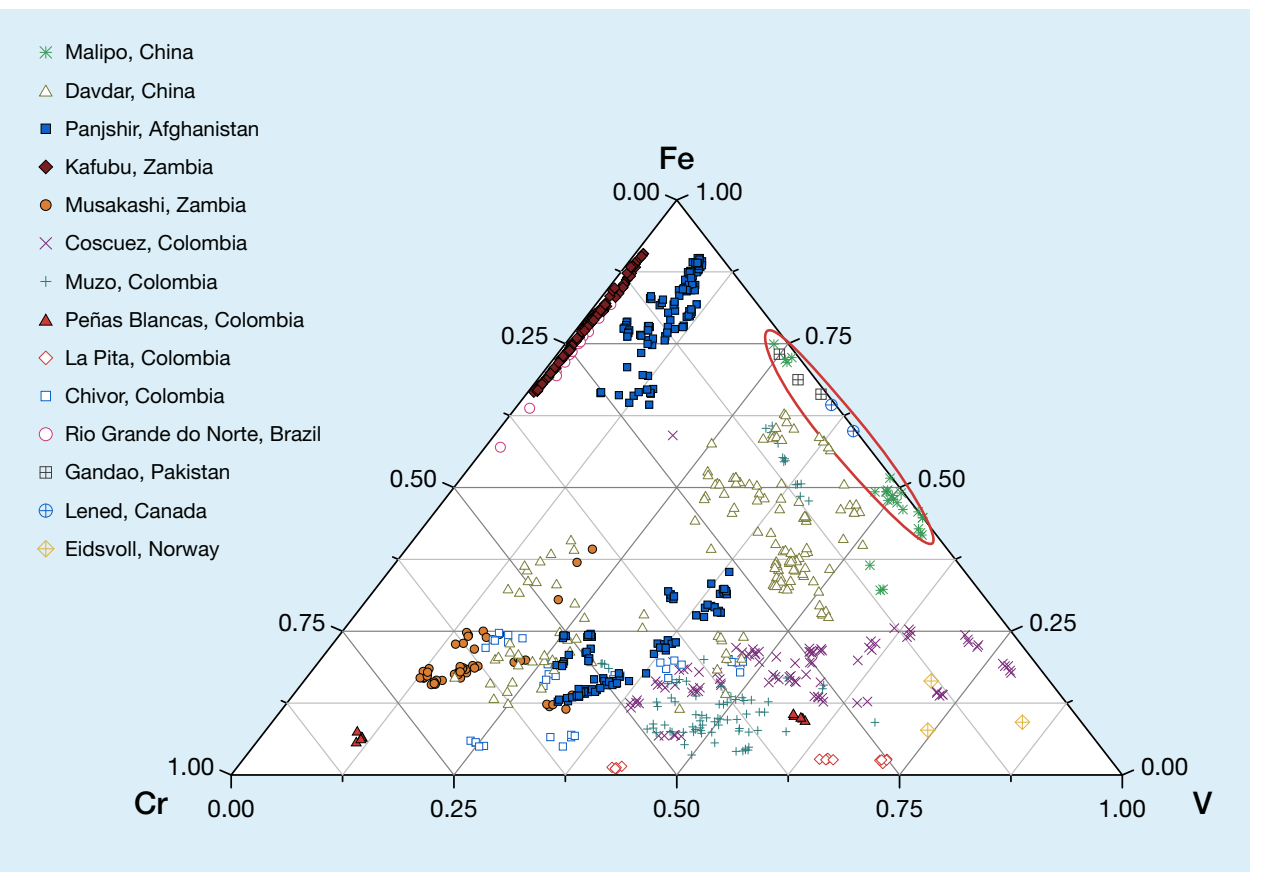

Figure 15. Plot of Fe$\mathrm{Cr}-\mathrm{V}(\mathrm{ppmw}) \mathrm{chemical}$ composition for emeralds from Malipo and other localities. The plot field of Malipo emeralds (within the red oval) was distinctive for the combination of high $\mathrm{V}$, low $\mathrm{Cr}$, and moderate Fe content. Other sources are from Hammarstrom (1989), Marshall et al. (2004), Rondeau et al. (2008), Marshall et al. (2012), Zwaan et al. (2012), and Saeseaw et al. (2014).

calities. Moreover, the plot field of Fe-Cr-V chemical composition was quite distinctive for Malipo emerald, though there was some overlap with Gandao and Lened emeralds. Li and Cs contents were previously unreported for Gandao emerald, and Cs content (850-1590 ppmw) of Lened emerald (Marshall et al., 2004) was just slightly lower than that of Malipo emerald. Therefore, concentrations of Li and Cs were not available to effectively separate Gandao and Lened emeralds. As emeralds from these two deposits are not found in large quantities on the gem market, this overlap has little influence on geographic origin determination. In addition, $\mathrm{Li}$ and Cs concentrations of Malipo emerald were close to Kafubu, but the difference in Fe-Cr-V chemical composition offered a straightforward means to distinguish them.

Color Characteristics. Trivalent vanadium was the predominant chromophore for Malipo emeralds, leading to a typically yellowish green color. Malipo emerald contained distinctly high vanadium content and showed the main absorption of $\mathrm{V}^{3+}$ ions in the visible light region. Ionic radii of $\mathrm{V}^{3+}(0.640 \AA)$ were close to $\mathrm{Al}^{3+}(0.535 \AA)$ in the six-fold coordinated octahedral site (Shannon, 1976), facilitating effective substitution of isovalent $\mathrm{V}^{3+}$ for $\mathrm{Al}^{3+}$ in the $\mathrm{AlO}_{6}$ octahedral site. The $\mathrm{AlO}_{6}$ octahedron is the key coloring structural unit in both beryl and a few important gems (e.g., sapphire, jadeite, and chrysoberyl). Their coloring characteristics from $\mathrm{Cr}^{3+}, \mathrm{Fe}^{2+}, \mathrm{Fe}^{3+}$, and $\mathrm{V}^{3+}$ appear to follow the typical crystal field behaviors of
$\mathrm{AlO}_{6}$ octahedra, which directly lead to gem colors. Incorporation of abundant $\mathrm{V}^{3+}$ ions in the $\mathrm{AlO}_{6}$ octahedral site was responsible for the yellowish green color of Malipo emeralds. Compared with emerald colored by $\mathrm{Cr}^{3+}$ ions, the color caused by $\mathrm{V}^{3+}$ tended to be more yellowish, owing to stronger absorption in the violet to blue region.

A significant anisotropic absorption band at 425$432 \mathrm{~nm}$ is an important spectral feature of $\mathrm{V}^{3+}$ in the $\mathrm{AlO}_{6}$ octahedral site of beryl and other minerals, such as corundum. $\mathrm{V}^{3+}$ ions substituting in similar $\mathrm{AlO}_{6}$ octahedra led to the anisotropic absorption centered at $400 \mathrm{~nm}$ in synthetic vanadium-dominated corundum (author's unpublished data). The absorption coefficient in the o-ray was twice as high as in the e-ray for emerald sample E4, which had almost no $\mathrm{Cr}$ (3-4 ppmw). This coefficient difference is the maximum value. With the ratio of $\mathrm{V}$ to $\mathrm{Cr}$ increasing, the difference of absorption coefficient between the o-ray and the e-ray would become larger (o-ray >eray), no more than double in emerald. Moreover, this absorption difference led to a noticeable yellowish green color in the o-ray and bluish green color in the e-ray under a polarized film (see inset photos in figure 12 ). And the color of the o-ray tended to be more yellowish as the V to Cr ratio increased.

The chromophore effectiveness of $\mathrm{V}^{3+}$ was expected to be comparable to that of $\mathrm{Cr}^{3+}$ ions in emerald. Absorption cross section is a constant for a particular chromophore in a specific matrix and could be used as an indication of chromophore effec- 
tiveness. Because an accurate cross section of $\mathrm{V}^{3+}$ and $\mathrm{Cr}^{3+}$ ions in emerald had not been investigated in previous studies, we estimated the cross section based on the Beer-Lambert law. Malipo emerald E7 contained V (3793 ppmw), a similar concentration level as the $\mathrm{Cr}$ (3347 ppmw) in Cr-dominated emerald (figure 21B in Saeseaw et al., 2014). The atomic weights of $\mathrm{V}$ and $\mathrm{Cr}$ are similar, and so are their atomic concentrations in ppma, which are used to compare the cross sections and chromophore effectiveness. At the same time, concentrations of $\mathrm{Cr}$ in sample E7 (105 ppmw) and V in Cr-dominated emerald (116 ppmw) were relatively low, so it was suitable to obtain the cross section of relatively pure $\mathrm{V}$ and $\mathrm{Cr}$. These two emerald samples showed a similar range of absorption coefficients, less than $7 \mathrm{~cm}^{-1}$ for $\mathrm{V}^{3+}$ and $\mathrm{Cr}^{3+} \mathrm{ab}$ sorption. So the calculated cross section of $\mathrm{V}^{3+}$ and $\mathrm{Cr}^{3+}$ should be similar. We concluded that the color effectiveness of $\mathrm{Cr}^{3+}$ and $\mathrm{V}^{3+}$ were comparable. In addition, Malipo V-rich emeralds and other Cr-rich emeralds containing similar amounts of $\mathrm{V}$ and $\mathrm{Cr}$, respectively, demonstrated a similar range of color saturations. Several thousand ppma of V or Cr could lead to a relatively saturated greenish color for emerald. More quantitative data are needed to compare color effectiveness of $\mathrm{Cr}^{3+}$ and $\mathrm{V}^{3+}$ in the future.

Transition elements other than vanadium had little effect on coloration in our samples. The $\mathrm{Cr}$ ion absorption was rather weak for the low level of $\mathrm{Cr}$ content determined, so the coloration produced by $\mathrm{Cr}$ was weak for Malipo emeralds. The broad absorption band centered at $620 \mathrm{~nm}$ could add a bluish color to emerald, especially in the e-ray, caused by
$\mathrm{Fe}^{2+}-\mathrm{Fe}^{3+}$ pairs (Lin et al., 2013). However, this band was nearly invisible because of insufficient Fe content in Malipo emeralds. The tail of a moderate 830 $\mathrm{nm} \mathrm{Fe}{ }^{2+}$-related band seems to extend slightly into the visible light region (again, see figure 12). Because the strong tail was also present in colorless beryl, this tail could not produce any visible color for the emerald samples.

\section{CONCLUSIONS}

A significant granite-related emerald occurrence is situated in Malipo County in China, a region with rich natural mineral and strategic ore resources. Mineral specimens, carvings, and faceted gems from the Malipo emerald deposit have been produced since the 1990s.

The scene of multiphase inclusions in Malipo emerald is distinctive, with various shapes and occasionally a colorless transparent crystal. Abundant vanadium (averaging $3473 \mathrm{ppmw}$ ) is the predominant chromophore, leading to a typically yellowish green color. Inadequate $\mathrm{Fe}$ and $\mathrm{Cr}$ contribute little to the color. The distinctive combination of high $\mathrm{V}$, moderate $\mathrm{Fe}$, and low $\mathrm{Cr}$ content separates this locality from most known emerald deposits. Moreover, the high Li and Cs content in Malipo emerald are unique among significant localities in the world, which can help in their geographic origin determination.

Emeralds have become part of the identity of Malipo as awareness of top-color stones has progressed in China in recent years. With abundant remaining emerald reserves, more production can be anticipated in the future.

\section{ABOUT THE AUTHORS}

Mr. Hu (huyang_gems@126.com) is a PhD student at the Gemological Institute, China University of Geosciences in Wuhan. Dr. Lu (renlu.cc@gmail.com) is a distinguished professor at the Gemological Institute, China University of Geosciences in Wuhan.

\section{ACKNOWLEDGMENTS}

The authors would like to thank Daowen Ye for providing Malipo emerald samples, valuable photos, and related information. We are also grateful to Dr. Robert Lavinsky for providing the photo from his collection. We sincerely thank Dr. George Rossman, Dr. Benjamin Rondeau, and an anonymous reviewer for their constructive comments and suggestions. This study was funded by the Center for Innovative Gem Testing Technology, China University of Geosciences (CIGTXM-S201821).

\section{REFERENCES}

Beckwith P.J., Troup G.J. (1973) The optical and infrared absorption of $\mathrm{V}^{3+}$ in beryl $\left(\mathrm{Be}_{3} \mathrm{Al}_{2} \mathrm{Si}_{6} \mathrm{O}_{18}\right)$. Physica Status Solidi, Vol. 16, No. 1, pp. 181-186, http://dx.doi.org/10.1002/pssa.2210160119

Feng M.G., Zhang S.T., Lu W. (2000) Geological characters of the
Chinese emerald deposit. Yunnan Geology, Vol. 19, pp. 37-42 [in Chinese].

Gaite J.M., Izotov V.V., Nikitin S.I., Prosvirnin S.Y. (2001) EPR and optical spectroscopy of impurities in two synthetic beryls. Ap- 
plied Magnetic Resonance, Vol. 20, No. 3, pp. 307-315, http://dx.doi.org/10.1007/BF03162283

Groat L. A., Giuliani G., Marshall, D.D., Turner D. (2008) Emerald deposits and occurrences: a review. Ore Geology Reviews, Vol. 34, No. 1-2, pp. 87-112, http://dx.doi.org/10.1016/j.oregeorev. 2007.09.003

Hammarstrom J.M. (1989) Mineral chemistry of emeralds and some associated minerals from Pakistan and Afghanistan: An electron microprobe study. In A.H. Kazmi and L.W. Snee, Eds., Emeralds of Pakistan: Geology, Gemology et Genesis. Van Nostrand Reinhold, New York, pp. 125-150.

Huang W.Q., Ni P., Shui T., Yang P. (2015) Mineralogical characteristics of emerald from Malipo, Yunnan Province. Acta Petrologica et Mineralogica, Vol. 34, No. 1, pp. 103-109 [in Chinese].

Huang W.Q., Shui T., Ni P. (2017) Fluid inclusion studies on emeralds from Malipo area, Yunnan Province, China. Acta Mineralogica Sinica, Vol. 37, No. 1/2, pp. 75-82 [in Chinese].

Hutton D.R., Darmann F.A., Troup G.J. (1991) Electron spin resonance of $\mathrm{V}^{4+}\left(\mathrm{VO}^{2+}\right)$ in beryl. Australian Journal of Physics, Vol. 44, No. 4, pp. 429-434, http://dx.doi.org/10.1071/PH910429

Jin Y.H., Yang B.Q. (1943) Genesis and significance of Laojunshan scheelite deposit in Wenshan, Yunnan. Geological Review, Vol. 8, No. Z1, pp. 170-171 [in Chinese].

Lin J., Chen N., Huang D., Pan Y. (2013) Iron pairs in beryl: New insights from electron paramagnetic resonance, synchrotron $\mathrm{X}$-ray absorption spectroscopy, and ab initio calculations. American Mineralogist, Vol. 98, No. 10, pp. 1745-1753, http://dx.doi.org/10.2138/am.2013.4472

Liu Y.S., Hu Z.C., Gao S., Günther D., Xu J., Gao C.G., Chen H.H. (2008) In situ analysis of major and trace elements of anhydrous minerals by LA-ICP-MS without applying an internal standard. Chemical Geology, Vol. 257, No. 1-2, pp. 34-43, http://dx.doi.org/10.1016/j.chemgeo.2008.08.004

Marshall D.D., Groat L.A., Falck H., Giuliani G., Neufeld H. (2004) The Lened emerald prospect, Northwest Territories, Canada: Insights from fluid inclusions and stable isotopes, with implications for Northern Cordilleran emerald. Canadian Mineralogist, Vol. 42, No. 5, pp. 1523-1539, http://dx.doi.org/10.2113/gscanmin.42.5.1523

Marshall D.D., Pardieu V., Loughrey L., Jones P., Xue G. (2012) Conditions for emerald formation at Davdar, China: fluid inclusions, trace element and stable isotope studies. Mineralogical Magazine, Vol. 76, No. 1, pp. 213-226, http://dx.doi.org/ 10.1180/minmag.2012.076.1.213

Ohkura H., Hashimoto H., Mori Y., Chiba Y., Isotani S. (1987) The luminescence and ESR of a synthetic emerald and the natural ones mined from Santa Terezinha in Brazil. Japanese Journal of Applied Physics, Vol. 26, No. 26, pp. 1422-1428, http://dx.doi.org/10.1143/JJAP.26.1422

Rondeau B., Fritsch E., Peucat J.J., Nordrum F.S., Groat L. (2008) Characterization of emeralds from a historical deposit: Byrud (Eidsvoll), Norway. GÆG, Vol. 44, No. 2, pp. 108-122,
http://dx.doi.org/10.5741/GEMS.44.2.108

Rossman G.R. (2014) Optical spectroscopy. Reviews in Mineralogy and Geochemistry, Vol. 78, No, 1, pp. 371-398, http://dx.doi.org/10.2138/rmg.2014.78.9

Saeseaw S., Pardieu V., Sangsawong S. (2014) Three-phase inclusions in emerald and their impact on origin determination. $G \uplus G$, Vol. 50, No. 2, pp. 114-132, http://dx.doi.org/10.5741/ GEMS.50.2.114

Schmetzer K. (1978) Vanadium III als Farbträger bei natürlichen Silikaten und Oxiden - ein Beitrag zur Kristallchemie des Vanadiums. Inaugural-Dissertation zue Erlangung der Doktorwürde des Naturwissenschaftlichen Gesamtfakultät der RuprechtKarl-Universität Heidelberg, 200 pp. [in German].

Schmetzer K., Schwarz D., Bernhardt H.J., Häger T. (2006) A new type of Tairus hydrothermally-grown synthetic emerald, coloured by vanadium and copper. Journal of Gemmology, Vol. 30 , No $1 / 2$, pp. $59-74$.

Schwarz D., Giuliani G. (2001) Emerald deposits-a review. Australian Gemmologist, Vol. 21, pp. 17-23.

Shannon R.D. (1976) Revised effective ionic radii and systematic studies of interatomic distances in halides and chalcogenides. Acta Crystallographica Section A, Vol. 32, Part 5, pp. 751-767, http://dx.doi.org/10.1107/S0567739476001551

Wang H.Q., Zhang S.T., Zhang M.W., Lu W., Li K.G. (1996) 1:10000 geologic mapping at the Dyakou emerald showing: Yunnan, China. Yunnan Geological Survey Report, 33 pp. [in Chinese].

Wood D.L., Nassau K. (1967) Infrared spectra of foreign molecules in beryl. The Journal of Chemical Physics, Vol. 47, No. 7, pp. 2220-2228, http://dx.doi.org/10.1063/1.1703295

Wood D.L., Nassau K. (1968) The characterization of beryl and emerald by visible and infrared absorption spectroscopy. American Mineralogist, Vol. 53, No. 5, pp. 777-800.

Xue G., Marshall D., Zhang S., Ullrich T.D., Bishop T., Groat L.A., Thorkelson D.J., Giuliani G., Fallick A.E. (2010) Conditions for Early Cretaceous emerald formation at Dyakou, China: Fluid inclusion, Ar-Ar, and stable isotope studies. Economic Geology, Vol. 105, No. 2, pp. 339-349, http://dx.doi.org/10.2113/ gsecongeo.105.2.339

Zhang L.J., Lan Y. (1999) Gemological characteristics and deposit geology of Yunnan emerald. Acta Mineralogica Sinica, Vol. 19, No. 2, pp. 189-197 [in Chinese].

Zhang S.T., Feng M.G., Lu W. (1998) Analysis of the Nanwenhe metamorphic core complex in southeastern Yunnan. Regional Geology of China, Vol. 17, p. 390-397 [in Chinese].

Zhang S.T., Feng M.G., Wang H.Q., Lu W., Yang M. (1999) Geological features and genesis of emerald deposit in Malipo County, Yunnan Province, China. Geological Science and Technology Information, Vol. 18, No. 1, pp. 50-54 [in Chinese]

Zwaan J.C., Jacob D.E., Häger T., Cavalcanti Neto M.T.O., Kanis J. (2012) Emeralds from the Fazenda Bonfim region, Rio Grande do Norte, Brazil. $G \uplus G$, Vol. 48, No. 1, pp. 2-17, http://dx.doi.org/10.5741/GEMS.48.1.2 